\title{
Studiowanie, kształcenie, oczekiwania - z badań studentów pierwszego roku
}

\section{Wprowadzenie}

Państwowe Wyższe Szkoły Zawodowe powstały w ośrodkach niemających tradycji akademickich, w miastach średniej wielkości, które w poprzednim podziale administracyjnym kraju pełniły funkcje miast wojewódzkich. Tego typu szkoła powstała w Suwałkach i w krótkim okresie stała się istotnym czynnikiem kulturotwórczym w lokalnym środowisku. Aktualnie kształcenie w wymienionej szkole realizowane jest na dwunastu kierunkach, w tym na trzech kierunkach o charakterze technicznym: budownictwo, transport, zarządzanie i inżynieria produkcji. Obszar, z którego rekrutują się studenci uczelni, to północna część województwa podlaskiego i wschodnia część województwa warmińsko-mazurskiego. Na każdym kierunku studiuje też pewna liczba studentów pochodzenia polskiego z Litwy, Białorusi lub Ukrainy. Kandydaci na studentów z reguły nie należą do elity absolwentów szkół średnich. Bywają wśród nich osoby, które musiały przystąpić do poprawki egzaminu maturalnego. Często są to kandydaci, którzy wcześniej ubiegali się o przyjęcie na studia w politechnikach lub uniwersytetach i nie przeszli pomyślnie procesu rekrutacji ${ }^{1}$.

$\overline{1}$ Por. M. Olejarz, Bariery w uczeniu się „młodych dorosłych” (w świetle badań jakościowych studentów animacji kultury Uniwersytetu Zielonogórskiego), [w:] T. Aleksander 
Jeśli przyjmiemy założenie, iż jednym z głównych celów utworzenia państwowych wyższych szkół zawodowych było wyjście naprzeciw potrzebom rynku pracy oraz aspiracjom młodzieży w obszarach oddalonych od centrów akademickich, to sensowne wydaje się ustalenie, czy istnieje zbieżność tych założeń $\mathrm{z}$ oczekiwaniami studentów wybierających tego typu uczelnię. Biorąc te uwarunkowania pod uwagę uznałem, iż celowe będzie dokonanie sondażu wśród studentów pierwszego roku kierunków technicznych dotyczącego ich przygotowania do procesu studiowania, umiejętności korzystania z oferty kształcenia oraz związanych z tym oczekiwań. Spodziewałem się także uzyskania chociażby częściowej odpowiedzi na pytanie: jaki rodzaj kształcenia jest preferowany przez studentów pierwszego roku: zgodnie z koncepcją Roberta J. Kidda - kształcenie w poziomie, kształcenie w pionie czy kształcenie w głąb?2 Zachodzi bowiem obawa, iż współczesny kandydat na studenta nie jest istotnie zainteresowany kształceniem w poziomie ani też kształceniem w głąb, lecz przede wszystkim jest zainteresowany kształceniem w pionie dającym formalny tytuł zawodowy potwierdzony odpowiednim dyplomem.

\section{Zarys metodologii badań}

Badania zostały przeprowadzone wśród studentów pierwszego roku trzech kierunków: budownictwa, transportu oraz zarządzania i inżynierii produkcji PWSZ w Suwałkach. Prowadząc na tych kierunkach zajęcia z matematyki oraz niektórych przedmiotów pokrewnych miałem możność zgromadzenia informacji o zagadnieniach, które są przedmiotem badań. Dodatkowo przeprowadzono badania ankietowe przy użyciu kwestionariusza zawierającego zarówno pytania zamknięte jak i otwarte. Pytania umożliwiały studentom dość szerokie i swobodne wypowiedzi na temat oferty kształcenia, procesu studiowania oraz oczekiwań związanych z wybranym kierunkiem studiów.

(red.), Edukacja dorosłych jako czynnik rozwoju społecznego, t. 2, Wydawnictwo Naukowe Instytutu Technologii Eksploatacji - Państwowy Instytut Badawczy, Radom 2010, s. 259-263.

2 Zob. A. Frąckowiak, Kształcenie ustawiczne i szkoły wyższe - niedostrzegany potencjał, Wydawnictwo Naukowe Instytutu Technologii Eksploatacji - Państwowy Instytut Badawczy, Radom 2012, s. 83. 
Celem badań było uzyskanie m.in. odpowiedzi na pytania:

1) W jakim stopniu studenci są przygotowani do trudnego dla nich zadania, jakim jest studiowanie na pierwszym roku kierunku technicznego, na którym dominują przedmioty podstawowe (matematyka, fizyka, chemia, statystyka)?

2) Jak adaptują się do nowych form i metod kształcenia, stawianych wymagań, konieczności samodzielnego organizowania procesu uczenia się i osiągania założonych efektów?

3) Czy oczekiwania studentów są zbieżne z formalnie określonymi celami i efektami kształcenia w wyższej szkole zawodowej?

Na pytania przedstawione w kwestionariuszu ankiety odpowiedziało 75 studentów pierwszego roku, co stanowi około $60 \%$ ogółu. Ponadto uzyskałem kilkanaście odrębnych wypowiedzi na temat przedstawionych zagadnień. Dane te pozwalają na pewne uogólnienia z zastrzeżeniem, iż odnoszą się one do określonego środowiska, w tym przypadku środowiska studentów uczelni oddalonej od centrów akademickich, studentów wybierających określone kierunki studiów niekoniecznie z powodu konkretnych aspiracji lecz innych uwarunkowań: odległości do uczelni, warunków materialnych, mierzenia zamiarów według możliwości i innych. Tym niemniej niektóre konstatacje wydają się być na tyle zbieżne $\mathrm{z}$ ogólnymi trendami w środowisku akademickim, iż można je rozciągnąć na szerszy obszar kształcenia w wyższych uczelniach technicznych. Dają do tego podstawę zaobserwowane wśród badanych studentów postawy charakterystyczne dla członków społeczeństwa konsumpcyjnego, którym chcąc nie chcąc stajemy się (w różnym tempie, lecz młodzież raczej szybko) ${ }^{3}$.

\section{Studiowanie}

Rozpoczynający studia spotykają nowe dla nich formy i metody kształcenia (wykłady, ćwiczenia audytoryjne, ćwiczenia projektowe, ćwiczenia laboratoryjne), wymagające zupełnie innego podejścia niż było praktykowane w ich dotychczasowej szkolnej edukacji. Proces adaptacji i wdrażania się do nowego stylu pracy nie zawsze przebiega bezproblemowo i wielu studentów napotyka istotne trudności.

3 Por. E. Skibińska, Cele edukacji dorosłych w kontekście społeczeństwa konsumentów, [w:] T. Aleksander (red.), Edukacja dorosłych jako czynnik rozwoju społecznego..., s. 47. 
Najczęściej wskazywaną przyczyną takich trudności była duża ilość nowych, nieznanych treści przekazywanych na wykładach. Wskazało ją 61\% badanych. W kolejności wskazywano:

- szybkie tempo wykładu - 45;

- niezrozumiały język używany przez wykładowcę - 36\%;

- brak umiejętności przekazywania wiedzy przez prowadzącego zajęcia-14\%;

- braki w wiedzy wyniesionej ze szkoły - 11\%;

- niesprzyjająca atmosfera na zajęciach - 11\%.

Uzyskane wyniki nie stanowią zaskoczenia z jednym wyjątkiem: niewielu badanych studentów jako istotną przyczynę trudności podało braki w wiedzy wyniesionej ze szkoły. Z mojej praktyki jako wykładowcy wynika, iż jest to istotny czynnik, przede wszystkim w przypadku takich przedmiotów jak matematyka czy fizyka. Taki wynik jest zbieżny z dokonanymi w innych uczelniach badaniami dotyczącymi odpowiedzialności podmiotów w procesie kształcenia ${ }^{4}$.

Istotną uwagę poświęciłem uzyskaniu odpowiedzi na pytanie, czy język używany przez wykładowców jest zrozumiały dla studentów pierwszego roku. Aż 66\% badanych stwierdziło, iż tylko około 50\% wykładowców używa w pełni zrozumiałego dla nich języka. Jedynie $20 \%$ badanych stwierdziło, iż większość przekazywanych treści jest dla nich zrozumiała. Odpowiedzi pozostałych były wręcz zatrważające. Przypuszczam, że jedną z istotnych przyczyn tego stanu rzeczy jest dość powszechnie spotykany we współczesnym młodym pokoleniu ubogi zasób słownictwa, będący następstwem przyjętego stylu życia, wpływów popkultury i zanurzenia w „społeczeństwo obrazkowe”.

W toku studiów przewidziane są konsultacje, które powinien prowadzić każdy wykładowca. Zadano badanym studentom pytanie - jak często korzystają z tej formy wsparcia. Uzyskano wyniki:

- często - $14 \%$ badanych;

- 3-4 razy w semestrze $-11 \%$ badanych;

- 1-2 razy w semestrze $-48 \%$ badanych;

- w ogóle nie korzystam - $27 \%$ badanych.

$4 \quad$ Por. A. Krajewska, Współdziałanie dydaktyczne podmiotów w fazach procesu kształcenia w ocenia studentów i nauczycieli, [w:] A. Karpińska, M. Zińczuk, P. Remża (red.), Oblicza edukacji w prospektywnym oglądzie, Wydawnictwo Adam Marszałek, Toruń 2019, s. 141-142. 
W zestawieniu $\mathrm{z}$ wynikami dotyczącymi rozumienia treści wykładów są to wyniki zastanawiające. Najczęściej podawaną przyczyną nieczęstego korzystania z konsultacji był brak czasu. Można to uznać w przypadku słuchaczy studiujących niestacjonarnie, natomiast w przypadku studentów stacjonarnych ten powód wydaje się wyolbrzymiony. Dociekając przyczyn tego zjawiska warto zauważyć występujący wśród absolwentów polskich szkół średnich syndrom wyuczonej bezradności ${ }^{5}$ Tempo zmian w świadomości i mentalności wśród kolejnych roczników młodego pokolenia jest tak duże, że nie zawsze z odpowiednią wyrazistością zauważamy, jak dalece obowiązujący system edukacji na niższych poziomach kształcenia „produkuje” absolwentów niepotrafiących organizować najprostszych form pracy w obszarze własnej edukacji. Wyuczona bezradność manifestuje się też w trakcie posługiwania się przez studentów nowoczesnymi technikami informatycznymi. Korzystający z programów komputerowych lub zasobów Internetu studenci na ogół nie potrafią krytycznie spojrzeć na uzyskane (często zupełnie błędne) wyniki, a tym bardziej je zweryfikować. Sądzę, iż temu zjawisku w dydaktyce szkoły wyższej poświęca się wciąż zbyt mało uwagi, a można zaobserwować jego narastanie.

Nieodłącznym elementem każdego procesu edukacyjnego jest kontrola i ocena uzyskanych efektów kształcenia. Badanych studentów zapytano, jak oceniają stosowane w uczelni formy kontroli i oceny ich pracy. W 66\% przypadków studenci ocenili stosowane formy i metody jako właściwe. Niezbyt istotne zastrzeżenia miało $32 \%$ badanych, tylko $2 \%$ uznało, iż stosowane formy im nie odpowiadają. Jeśli weźmie się pod uwagę fakt, że obecnie studiujący mają za sobą cztery etapy kształcenia kończące się egzaminami, to taki wynik wydaje się niemalże oczywisty. Można więc sformułować wniosek, iż jedynym pozytywnym efektem rozbudowanego systemu egzaminów w polskim szkolnictwie jest zaobserwowana wśród studentów umiejętność zdawania egzaminów i zaliczania kolokwiów czyli - inaczej mówiąc - wyuczona zaradność w tym zakresie.

W obowiązującym systemie punktów ECTS uznaje się, iż każdy punkt wymaga 25-30 godzin pracy studenta w formie zajęć z wykładowcami

$5 \quad$ Zob. J. Mańczak, Kompetentny zawodowo nauczyciel akademicki w opinii studentów, [w:] K. Jaskot, E. Radecki (red.), Pedagogika szkoły wyższej, nr 16, Oficyna Wydawnicza ROKP Zachodniopomorskiego Centrum Edukacyjnego, Szczecin 2001, s. 138. 
oraz własnej. Jeśli weźmiemy pod uwagę konieczność uzyskania przez studenta co najmniej 30 punktów ECTS w semestrze, to nakład czasu jego pracy wyniesie 750-900 godzin, co wydaje się wielkością nieco zawyżoną. Studenci pytani o nakład ich pracy w zestawieniu z wymogami systemu punktów RCTS stwierdzili, że taki wymiar jest bliski rzeczywistości (68\% odpowiedzi). W 32\% udzielonych odpowiedzi stwierdzano, iż jest to wielkość zawyżona i studiowanie (mimo sygnalizowanych opinii o wydłużaniu czasu zajęć) nie wymaga w ich przypadku takiego nakładu czasu. Jest to kolejne potwierdzenie oczywistego faktu, iż odgórne normowanie wszelkich czynności w procesie studiowania, w tym nakładu czasu pracy studenta jest swego rodzaju fikcją. Każdy student pracuje we właściwym dla siebie tempie, a indywidualne różnice są często bardzo duże $\mathrm{e}^{6}$.

\section{Kształcenie}

Aspirujący do ukończenia studiów wyższych kandydat na studenta spotyka się z ofertą wybranej uczelni, dotyczącą kierunków, specjalności, planu studiów w zakresie przedmiotów obowiązkowych i fakultatywnych. Wybierając konkretny kierunek i specjalność godzi się na określony tok studiów, zestaw przedmiotów, a zatem i prowadzących je wykładowców. W przeprowadzonych badaniach nie formułowałem pytań wymagających od studentów głębokiej oceny form, metod i środków kształcenia stosowanych przez prowadzących zajęcia, ponieważ uznałem, iż obraz, jaki wytworzył się w ich świadomości po pierwszym roku studiów (dla części z nich bardzo trudnym) jest nie do końca obiektywny. Tym niemniej z uzyskanych odpowiedzi można utworzyć w miarę spójny obraz systemu kształcenia w uczelni, jaki funkcjonuje w świadomości studentów.

Charakterystyczną jego cechą jest - jak już wcześniej wspomniano - duża ilość nowego, trudnego, wymagającego wysiłku niezbędnego dla rozumienia materiału stanowiącego treść wykładów i ćwiczeń. Jednocześnie badani studenci dość wysoko ocenili umiejętności pedagogiczne wykładowców, umiejętność zrozumiałego przedstawiania

$6 \quad$ Por. A. Krajewska, Działania wielopodmiotowe w nowoczesnym procesie kształcenia w szkole wyższej, [w:] A. Karpińska (red.), Edukacja w okresie przemian, Wydawnictwo Trans Humana, Białystok 2009, s. 115. 
treści wykładów (ponad 50\% odpowiedzi było pozytywnych). Jedynie $11 \%$ badanych studentów negatywnie wyraziło się o umiejętnościach wykładowców w tym zakresie.

W planie pierwszego roku studiów technicznych są z konieczności przewidziane przedmioty kształcenia podstawowego: matematyka, fizyka, chemia, statystyka. Programy tych przedmiotów są w pewnym zakresie kontynuacją kształcenia w szkołach kończących się maturą. Czy zatem student pierwszego roku może napotkać istotne trudności w przyswajaniu zawartej w nich wiedzy? Z przeprowadzanych badań wynika, że spośród przedmiotów podstawowych jako ten, który sprawiał największe kłopoty została wymieniona jedynie matematyka (16\% badanych). Z własnych doświadczeń mogę wnioskować, iż jedną z przyczyn trudności w opanowaniu wiedzy w zakresie wyższej matematyki może być stosunkowo mała liczba godzin przewidziana na ten przedmiot w planie studiów. Wymaga to dość intensywnej pracy na wykładach i ćwiczeniach, a nie jest to okoliczność sprzyjająca kształceniu matematycznemu. Problem ma też głębsze podłoże. Kultywowana przez pokolenia opinia o wyjątkowej trudności czy też nieprzystępności wiedzy matematycznej dla przeciętnego umysłu tworzy określone nastawienia, a co gorsze, uprzedzenia. We współczesnym świecie i na obecnym etapie rozwoju matematyki jest ona nauką mającą dwa zasadnicze aspekty: coraz większe zastosowanie praktyczne oraz (najczęściej niedoceniany) aspekt humanistyczny? ${ }^{7}$ Przedmiotami, które sprawiły problem badanym studentom okazały się przedmioty związane z obranym kierunkiem studiów: mikro- i makroekonomia - 34\% wskazań, geometria wykreślna - 32\% wskazań oraz podstawy konstrukcji maszyn - 27\% wskazań. Jako podstawową przyczynę trudności studenci podawali: duża ilość materiału przy stosunkowo niewielkim wymiarze godzin przeznaczonych na te przedmioty. Należy zwrócić uwagę, iż są to przedmioty wymagające zastosowań matematyki, zatem sygnalizowane trudności mogą mieć także przyczynę - jak wcześniej wspomniałem - w syndromie wyuczonej bezradności oraz związanej z tym nieporadności intelektualnej.

$7 \quad$ Zob. A. Pardała, Wyzwania humanizacji matematyki, dydaktyki matematyki i pedagogiki twórczości, [w:] J. Łaszczyk (red.), Filozofia i pedagogika twórczości-gtówne problemy, zasadnicze rozstrzygnięcia, Wydawnictwo Universitas Rediviva, Warszawa 2011, s. 304. 
Nieodłącznym elementem procesu kształcenia jest kontrola i ocena osiągniętych efektów. W praktyce akademickiej odbywa się to najczęściej w formie egzaminów, kolokwiów, prac projektowych, sprawozdań z ćwiczeń laboratoryjnych, pisemnych opracowań podanych zagadnień. Badani studenci uznali stosowane formy kontroli efektów kształcenia za właściwe (w 66\% odpowiedzi nie formułowano zastrzeżeń). Jedynie jedna forma nie zyskała powszechnej akceptacji. Są to sprawozdania z przeprowadzonych ćwiczeń laboratoryjnych oceniane przez prowadzących takie ćwiczenia. Sądzę, iż przyczyny tego stany rzeczy tkwią w zjawisku, które wcześniej określiłem jako wyuczoną bezradność. Egzaminy, pisemne kolokwia, sprawdziany testowe nie są dla studentów pierwszego roku nowością. Co więcej, wielu z nich opanowało swoistą formę pracy zespołowej, polegającą na indywidualnym opracowywaniu pojedynczych zagadnień egzaminacyjnych, a następnie tworzeniu całościowego opracowania do użytku dla całej grupy (znów daje znać „wyuczona zaradność”) dania z wykonanych ćwiczeń laboratoryjnych wymagają starannego opracowania, analizy wyników, formułowania wniosków, krytycznego spojrzenia na efekty. W dotychczasowej edukacji raczej rzadko wymagano takiej aktywności, zatem tego typu umiejętności nie są mocną stroną studentów pierwszego roku i często stają oni bezradni wobec stawianych im wymagań.

Nawiązując do zasygnalizowanego we wstępie zagadnienia dotyczącego kształcenia w poziomie, w pionie i w głąb można stwierdzić, iż badani studenci są zainteresowani kształceniem w pionie, kształcenie w poziomie traktują jako zdobywanie niezbędnych kwalifikacji, przydatnych w przyszłej pracy zawodowej, natomiast kształcenie w głąb czyli rozwijanie własnej osobowości, zdobywanie tzw. miękkich kwalifikacji nie jest ich priorytetem.

8 Por. L. Pacan, Transgresje w odniesieniu do kreowania (pseudo)wartości u studentów pedagogiki, [w:] J. Górniewicz (red.), Edukacja - w stronę kluczowych wartości, Centrum Badań Społecznych Uniwersytetu Warmińsko-Mazurskiego, Olsztyn - Białystok 2017, s. 97. 


\section{Oczekiwania}

Wybierając określony kierunek studiów kandydat na studenta tworzy swoisty pakiet oczekiwań wobec tego, co może mu dać ten nowy dla niego okres życiowej aktywności. Oczekiwania można ogólnie skategoryzować w dwóch zasadniczych obszarach; w pierwszym związane są one z ofertą edukacyjną uczelni, sylwetką absolwenta, którym kandydat ma się stać; w drugim obszarze oczekiwań związane są one $\mathrm{z}$ wyobrażeniami dotyczącymi nowych form zajęć, aktywności studenckiej, relacjami pomiędzy wykładowcami i studentami.

Badani stwierdzali, że oferta edukacyjna uczelni w zakresie obranego kierunku studiów odpowiada ich aspiracjom i spełnia ich oczekiwania. Rozbieżności w wypowiedziach dotyczyły czasu pracy studenta oraz liczby godzin przeznaczonych na niektóre przedmioty. $Z$ jednej strony, sygnalizowano duże obciążenie studentów zajęciami, z drugiej, postulowano, aby zwiększyć liczbę godzin przewidzianych na realizację przedmiotów zawierających dużo nowych trudnych pojęciowo zagadnień. Postulowano też wprowadzenie większej dowolności w wyborze przedmiotów, czyli zwiększenie liczby przedmiotów fakultatywnych. W jednym przypadku był to postulat indywidualizacji toku studiów nie tylko dla wyróżniających się studentów lecz jako zasada. Zgłoszono także interesujący postulat dotyczący form motywowania studentów. Polega on na tym, aby wyróżniający się studenci mogli korzystać z bardziej elastycznych form zaliczania przedmiotów, natomiast nie powinno się stosować żadnych ułatwień wobec studentów lekceważących obowiązki.

$\mathrm{Na}$ uwagę zasługują odpowiedzi badanych studentów dotyczące formy zakończenia studiów inżynierskich. Znakomita większość z nich uważa, że najlepszą formą byłoby opracowanie przez 2-3 osobowe grupy konkretnych, mogących mieć praktyczne zastosowanie projektów i zaprezentowanie ich komisji egzaminacyjnej. Taką opcję postulowało $66 \%$ badanych. Za dotychczasową formą pisania pracy dyplomowej-inżynierskiej opowiedziało się 32\% badanych, a tylko $4 \%$ uznało, iż najlepszą formą byłby egzamin końcowy bez pisania pracy dyplomowej. Może to świadczyć o istnieniu w świadomości studentów potrzeby uzyskania w każdy możliwy sposób jak najwyższych kwalifikacji użytecznych w przyszłej pracy zawodowej. Koresponduje to 
z pojawiającymi się wypowiedziami postulującymi zwiększenie liczby zajęć praktycznych i wyraźniejszego akcentowania praktycznych zastosowań treści wykładanych przedmiotów.

W drugiej sferze oczekiwań można pomieścić postulaty dotyczące sposobu prowadzenia zajęć, efektywności zajęć, rzetelności oceniania, postaw wykładowców i stosunków interpersonalnych. Zasygnalizowano tylko jeden przypadek wykładowcy, który swą postawą dał powód do negatywnej oceny przez studentów. W pozostałych wypowiedziach dotyczących sposobu prowadzenia zajęć, stosunku do studentów, wiedzy i kwalifikacji wykładowców przeważały zdecydowanie opinie pozytywne. Może to świadczyć o właściwie ukształtowanych relacjach w badanej minispołeczności, a także - co istotne - pozytywnie o umiejętnościach dydaktycznych wykładowców. Praktycznie też nie odnotowano wypowiedzi nawiązujących wprost do nieakceptowanych cech, postaw lub zachowań wykładowców (z jednym wyjątkiem, o czym już wspomniałem). Z prowadzonych w wielu uczelniach badań wynika, iż studenci nierzadko formułują pryncypialne, wyraziste, często roszczeniowe opinie wobec wykładowców ${ }^{9}$. W tym kontekście można zatem twierdzić, iż w opinii badanych studentów pierwszego roku wykładowcy spełniają ich oczekiwania, prowadząc do pomyślnej kontynuacji studiów w kolejnych latach.

\section{Podsumowanie}

Przedstawione spostrzeżenia wynikające z badań, jakie przeprowadziłem wśród studentów pierwszego roku trzech kierunków: budownictwa, transportu oraz zarządzania i inżynierii produkcji PWSZ w Suwałkach. Ujmując hasłowo ich wyniki w trzy kategorie: studiowanie, kształcenie, oczekiwania, starałem się uzyskać obraz (z konieczności zapewne schematyczny i niepełny), w którym dociekałem, czy umiejętności studiowania zaprezentowane przez studentów pierwszego roku wystarczają im w zetknięciu z modelem kształcenia, jaki

$9 \quad$ Zob. W. Dróżka, Obraz nauczyciela akademickiego w świadomości studentów. Przyczynek do dyskusji, [w:] K. Jaskot, E. Radecki (red.), Pedagogika szkoły wyższej, nr 16, Oficyna Wydawnicza ROKP Zachodniopomorskiego Centrum Edukacyjnego, Szczecin 2001, s. 182-184. 
zastali w szkole wyższej i jakie w związku z tym są ich oczekiwania wobec uczelni i kadry prowadzącej zajęcia.

W zakresie pierwszej kategorii - studiowania udało się zaobserwować swoistą jednokierunkowość. Bardzo sztywny system klasowo-lekcyjny obowiązujący w polskiej edukacji, sztywne podstawy programowe, wysoce sformalizowany system ewaluacji wyników kształcenia przynosi efekty w postaci: z jednej strony dużej umiejętności pomyślnego zdawania pisemnych sprawdzianów, zwłaszcza jeśli mają formę testów; z drugiej, wyuczonej bezradności w przypadku konieczności bardziej twórczego podejścia do rozwiązywanego problemu. Dochodzi do tego powszechne lecz najczęściej bezrefleksyjne korzystanie z mediów elektronicznych. Informacje uzyskane z Internetu lub wyniki podane przez program komputerowy są najczęściej przyjmowane bezkrytycznie, nawet wtedy, gdy przeczy to zdrowemu rozsądkowi.

W drugiej kategorii - kształcenia zaobserwowano zbieżność aspiracji studentów $\mathrm{z}$ ofertą, jaką przedstawiła im uczelnia, zarówno co do treści, jak i formy zajęć. Biorąc jednak pod uwagę wypowiedzi części (bardziej ambitnych) studentów rodzi się pytanie: czy obrany w Polsce kierunek reform szkolnictwa wyższego, a przede wszystkim wyższego zawodowego jest zbieżny z misją szkolnictwa wyższego w społeczeństwie XXI wieku? ${ }^{10}$ Już powszechnie obowiązująca Polska Rama Kwalifikacji z istną lawiną formalistyczno-biurokratycznych konsekwencji wymagających od wykładowców schematycznych i nieelastycznych ujęć treści, które mają być przekazane studentom jest bardzo wątpliwą „pomocą” w ich naukowo-dydaktycznej działalności. Dodać do tego należy inspirowane neoliberalizmem podejście do roli wyższego szkolnictwa zawodowego $\mathrm{w}$ postindustrialnym społeczeństwie jako jedynie środka do produkcji wykwalifikowanych pracowników ${ }^{11}$. Te okoliczności wymuszają usztywnianie programów studiów, wykładowcy i studenci są traktowani przedmiotowo, w konsekwencji tracą na tym najbardziej ambitni i uzdolnieni studenci, a przecież to oni

10 Por. D. Jankowska, Efektywnośćlefektowność edukacji akademickiej - pomiędzy pragmatycznościa a upozorowaniem, [w:] A. Karpińska, W. Wróblewska (red.), Dydaktyka akademicka wybrane obszary badawcze, Wydawnictwo Akademickie Żak, Warszawa 2014, s. 95.

11 Zob. M. Furmańska, Szkolnictwo wyższe z ograniczona odpowiedzialnościa, [w:] A. Karpińska (red.), Kierunki rozwoju dydaktyki w dialogu i perspektywie, Wydawnictwo Difin, Warszawa 2011, s. 223. 
mogą w przyszłości wpływać na kształt naszego życia. Najbardziej niepokojące jest to, że takie uwarunkowania praktycznie uniemożliwiają kształcenie w głąb na szczeblu szkoły wyższej. Jest to niedoceniany i właściwie pomijany aspekt edukacji, który przecież powinien być traktowany pierwszoplanowo na każdym jej poziomie.

W trzeciej kategorii - oczekiwań dało się zaobserwować wśród badanych studentów świadomość istoty dokonanego wyboru formy i kierunku kształcenia. Akceptowane są zastane formy i metody kształcenia, kwalifikacje i umiejętności wykładowców. Badani studenci w większości nie mają rozbudzonej potrzeby kształcenia w głąb i nie zgłaszają takich oczekiwań. Dają się jednak też zauważyć postawy transgresywne, wychodzenie poza obowiązujące ramy (przynajmniej w sferze postulatów). W zestawieniu z tym, co zasygnalizowałem na wstępie o kandydatach na studentów PWSZ w Suwałkach daje to podstawy do wniosku, iż nawet w niedużych uczelniach oddalonych od centrów akademickich możliwa jest efektywna praca $\mathrm{z}$ ambitnymi, uzdolnionymi studentami, budującymi swą osobowość i przyszłą karierę zawodową.

\begin{abstract}
The results of a first year student survey are presented, divided into three categories: studying, education, expectations. In the first category, it was found that students have technical study skills. However, they do not have creative problem solving skills. In the second category, it was found that students accepted the forms and methods of education they at the university. In the third category, it was found that the university meets the students' expectations regarding their aspirations related to the choice of field and form of study. On the other hand, it is alarming to note that the surveyed students do not feel a significant need for in-depth education, i.e. enriching their personality with qualities necessary in their future professional life.
\end{abstract}

\title{
Bibliografia
}

Dróżka W., Obraz nauczyciela akademickiego w świadomości studentów. Przyczynek do dyskusji, [w:] K. Jaskot, E. Radecki (red.), Pedagogika szkoły wyższej, nr 16, Oficyna Wydawnicza ROKP Zachodniopomorskiego Centrum Edukacyjnego, Szczecin 2001. 
Frąckowiak A., Kształcenie ustawiczne i szkoły wyższe - niedostrzegany potencjał, Wydawnictwo Naukowe Instytutu Technologii Eksploatacji - Państwowy Instytut Badawczy, Radom 2012.

Furmańska M., Szkolnictwo wyższe z ograniczoną odpowiedzialnościa, [w: A. Karpińska (red.), Kierunki rozwoju dydaktyki w dialogu i perspektywie, Wydawnictwo Difin, Warszawa 2011.

Jankowska D., Efektywność/efektowność edukacji akademickiej - pomiędzy pragmatycznością a upozorowaniem, [w:] A. Karpińska, W. Wróblewska (red.), Dydaktyka akademicka wybrane obszary badawcze, Wydawnictwo Akademickie Żak, Warszawa 2014.

Krajewska A., Działania wielopodmiotowe $w$ nowoczesnym procesie kształcenia w szkole wyższej, [w:] A. Karpińska (red.), Edukacja w okresie przemian, Wydawnictwo Trans Humana, Białystok 2009.

Krajewska A., Współdziałanie dydaktyczne podmiotów w fazach procesu kształcenia w ocenia studentów i nauczycieli, [w:] A. Karpińska, M. Zińczuk, P. Remża (red.), Oblicza edukacji w prospektywnym ogladzie, Wydawnictwo Adam Marszałek, Toruń 2019.

Mańczak J., Kompetentny zawodowo nauczyciel akademicki w opinii studentów, [w:] K. Jaskot, E. Radecki (red.), Pedagogika szkoły wyższej, $n r$ 16, Oficyna Wydawnicza ROKP Zachodniopomorskiego Centrum Edukacyjnego, Szczecin 2001.

Olejarz M., Bariery w uczeniu się „młodych dorosłych” (w świetle badań jakościowych studentów animacji kultury Uniwersytetu Zielonogórskiego), [w:] T. Aleksander (red.), Edukacja dorosłych jako czynnik rozwoju społecznego, t. 2, Wydawnictwo Naukowe Instytutu Technologii Eksploatacji - Państwowy Instytut Badawczy, Radom 2010.

Pacan L., Transgresje w odniesieniu do kreowania (pseudo)wartości u studentów pedagogiki, [w:] J. Górniewicz (red.), Edukacja - w stronę kluczowych wartości, Centrum Badań Społecznych Uniwersytetu Warmińsko-Mazurskiego, Olsztyn - Bialystok 2017.

Pardała A., Wyzwania humanizacji matematyki, dydaktyki matematyki i pedagogiki twórczości, [w:] J. Łaszczyk (red.), Filozofia i pedagogika twórczości - główne problemy, zasadnicze rozstrzygnięcia, Wydawnictwo Universitas Rediviva, Warszawa 2011.

Skibińska E., Cele edukacji dorosłych w kontekście społeczeństwa konsumentów, [w:] T. Aleksander (red.), Edukacja dorosłych jako czynnik rozwoju społecznego, t. 2, Wydawnictwo Naukowe Instytutu Technologii Eksploatacji - Państwowy Instytut Badawczy, Radom 2010. 